\title{
Behavior Changes in Paulo Coelho Veronika Decides to Die:
}

\section{A Psychological Approach}

\author{
Bagas Suryo Prakoso \\ English Literature Department \\ Universitas Ahmad Dahlan \\ Indonesia \\ bagas1600026012@webmail.uad.ac.id \\ Resneri Daulay \\ English Literature Department \\ Universitas Ahmad Dahlan \\ Indonesia
}

Citation: Prakoso, B. S. \& Daulay, R. (2020). Behavior changes in Paulo Coelho veronica decides to die: a psychological approach. Notion: Journal of Linguistics, Literature, and Culture, Vol 2(2), p. 90-95. DOI: http://doi.org/10.12928/notion.v2i2.2880

\section{Article Info}

Article History

- Article Received $30^{\text {th }}$ September 2020

- Article Accepted $5^{\text {th }}$ November 2020

\section{Keywords}

motivation to life dysfunction behavior reciprocal determinism \& therapy

novel

personality

\section{ABSTRACT}

The purpose of this study is to analyze the personality of the main character presented in the novel. In addition, the aim of this research is to reveal the main character's environments contribute to the character's motivation to life. This novel conducted the struggle from Veronika as the main character for finding her motivation to life. This study used descriptive qualitative methods to analyze the data. This study used three main concepts of social cognitive theory by Albert Bandura (1986), they are reciprocal determinism, therapy, and dysfunction behavior/depression. This study also applied the theory of social cognitive theory in the book entitled The Theory of Personality by Jess Feist as a tool to analyze the personality of the main character also the main character's environments contributing to the character's motivation to life in the novel. The results are first, this study indicated personality of Veronika as the main character in the novel based on the social cognitive theory concept that is dysfunction behavior. It shows that Veronika is an introvert person, fainthearted, and suffering from depression. Second, this study discovered the main character's environments contribute to the character's motivation to life based on the social cognitive concepts, they are reciprocal determinism and therapy. Based on that theoretical concept, it shows that Veronika's environment really helps her to find her motivation to life. They are Mari, Zedka, and Edward. 


\section{Prakoso, Bagas Suryo \& Daulay, Resneri Behavior Changes in Paulo Coelho Veronika Decides to Die: A Psychological Approach}

\section{INTRODUCTION}

Literary works often give value to readers because they can be considered human reflection. The author of literary works often makes his works as an expression of reality that occurs in his life and environment. Meanwhile, literary works are not only used as an expression of the writer, but also, sometimes, a critique of reality. We can see that during the revolution in England, Charles Dickens described the social reality of the era by writing a literary work in the form of a novel, Oliver Twist[1][2]. Through literary works, readers are taken to see the world in a real and deeper way than everyday life. Therefore, there is a possibility that literary works will be able to open readers' knowledge about wider life. Meanwhile, literary works also help readers to better understand life and everything inside to create healthy and happy individuals.

Life itself has wide meaning. However, there are still many people who don't understand more about the meaning of life itself. Likewise, young people who are in the stage of looking for identity and they thoughts about what life really means and what life motivation is[3]. Among young people, many of them have not found a purpose or motivation for life is. And even, not a few of those who decide to end their life by suicide and by the reason of not having the motivation to live.

In this case, the researcher wants to discussed about what exactly motivation itself and how motivation obtained by changing behavior[4]. The word motivation comes from the Latin term meaning "to move". It means something that moves us. La Macchia \& Louis[5] said that a person's behavior is something that is constantly moving, so the main concept of his theory is motivation that keeps people moving. It means that motivation is what guides us to accomplish a goal. Our desire to do things that lead us to set and attain our goals.

Furthermore, the researcher wants to analyze a novel created by Brazilian novelist Paulo Coelho[6]. He was born on August 24, 1947, in Rio de Janeiro, Brazil. Coelho attended Jesuit schools and was raised by devout Catholic parents. Unfortunately, Coelho's talent was not approved by his parents. They did not want Coelho to become a writer. They prefer that Coelho be an architect or legal expert. But it seems that Coelho is not an obedient type of child. Thanks to his meeting with Henry Miller's book entitled Tropic of Cancer, he further to fuel the spirit of his rebellion. His father saw this as a symptom of a psychiatric disorder and he decided to send his child to a mental hospital. At the mental hospital, Coelho had to undergo electroconvulsive therapy (therapy by synchronizing electricity to the patient's body). This therapy is very dangerous because it can damage the human nerve tissue. This therapy was banned by the Brazilian government after Coelho revealed this dangerous practice in his novel Veronika Decides to Die. Coelho even had two times in and out of a mental hospital before finally being declared healed.

Paulo Coelho is one of the most widely read writers in the world today. According to Zolmedal[6] More than 86 million books by Paulo Coelho, translated into 67 languages, have been sold in 150 countries. One of Paulo Coelho's novels titled Veronica Decides to Die is colored by the author's intimate knowledge about the world of asylums, their relationships, and the comfort and anxiety of living in such a place. Readers can discover other parts of life that they have never met or even imagined before, the world of madness. The novel doesn't about the madness but also it discusses about the psychological condition of humans.

The reasons of the researchers want to research this novel are because it was made by a famous novelist who has received so many awards. Zolmedal[6] in his article said that, in 2001 Paulo was awarded the Bambi Award Germany's oldest and most respected award. And the following year in October 2002, Paulo received the Planetary Arts which is an international research platform that promotes the integration of art, science, technology, and consciousness research, under the rubric of techno etic arts. Moreover, the researcher wants to understand more about how Veronika as the main character gets motivation to life from the environment by changing her behavior. Veronika get the motivation from her three friends as the 
environments named Mari, Zedka, and Edward. Meanwhile, characterization also an important element found in literature, it is necessary to know the personality representation of the main character, and the behavior of the character. Psychological approach also needed to analyze the characterization and the influence of the environment of the character in motivating her.

\section{METHODOLOGY}

The method of analyzing data is descriptive qualitative analysis[2]. Starting from reading the novel and also understanding every conversation of the main character with another character, the behavior of the main character, and others. Then the researcher browses some website to understand the theory, and also understand the theory by reading the book of theory. Furthermore, the researcher choosing Albert Bandura's theory named social cognitive theory as a theory for analyzing this research.

The researcher using this theory because social cognitive theory is related with problem formulation in this research. In this theory, there is an explanation of therapy, reciprocal determinism, and behavior dysfunction[7]. Theory of behavior dysfunction is related with the problem formulation number one that is personality of the main character presented in the novel. Meanwhile, theory of reciprocal determinism and therapy is related with the problem formulation number two that is the main character's environments contribute to the character's motivation for life. The last is matching the points of the theory with sentences or paragraphs which can be related with the theory. This way is done to analyzing this research.

\section{RESULT AND DISCUSSION}

In this chapter, the researcher would like to analyze the personality of the main character and the main character's environment contribute to finding the main character's motivation to life in the novel Veronika Decides to Die by Paulo Coelho used the social cognitive theory by Albert Bandura. this study indicated personality of Veronika as the main character in the novel Veronika Decides to Die based on the social cognitive theory concept that is dysfunction behavior. Based on concept of dysfunction behavior, it shows that Veronika is an introvert person, fainthearted, and suffering from depression. Second, this study discovered the main character's environments contribute to the character's motivation to life based on the social cognitive concepts, they are reciprocal determinism and therapy. Based on that theoretical concept, it shows that Veronika's environment really helps her to find her motivation to life. They are Mari, Zedka, and Edward. The data will be taken from the novel of Veronika Decides to Die[8].

\section{a. The Personality of the Main Character}

Regarding the concept of behavior, there five major personalities through perspective of Psychology[9], in which those will affect the motivation of life[10][11][12].

\section{1) Introvert}

Veronika is also characterized as an introvert person. She never shares about her truly life and feelings to her closest people even she has so many friends. She prefers to keep everything for her own. On the other hand, she prefers spending the night alone to having comparison to share since she thinks that sharing would never bring any differences to the problem and sadness she faces. In fact, she realizes that she definitely needs people to be happy in life. Because of that she never had never enough energy to be herself, a person. Who like everyone else in the world, needed other people in order to be happy. But other people were so difficult.... When someone more open to life appeared, they either rejected them outright or made them suffer, conigning them to being inferior, ingenuous."

\section{2) Fainthearted}

Not only being described as an introvert person, Veronika is also described as a fainthearted and woman since she always chooses the easy options of all aspects in her life even by her time of committing suicide. It is all because is too afraid to take the risks. It makes her a pessimistic person who feel afraid in doing things including in forming relationship with others since she thinks that at the end, this relationship will end in vain. Veronika tends to view things form the negative sides that prevent her to do things she wants. "While she was waiting for death, Veronika started reading about computer science, a 


\section{Prakoso, Bagas Suryo \& Daulay, Resneri Behavior Changes in Paulo Coelho Veronika Decides to Die: A Psychological Approach}

subject in which she was not the least interested, but then that was in keeping with that she had done all her life, always looking for the easy option, for whatever was nearest at hand. Like the magazine, for examples (Coelho, 1998: 3)."

\section{3) Depressed}

Veronika is a person who does not believe in her own abilities. She always blames herself. Moreover, she does not believe that if she can survive from her suicide it would not guarantee some happiness for her. Meanwhile, she thinks that she could not do anything. Therefore, she is afraid to do anything. According to Albert Bandura, he said that "Depressed people are more likely to make wrong judgments. They set unrealistic and very high standards, so any personal achievement will be judged as a failure. Depression is more likely to occur to those who set goals and personal standards that are far higher than their perceived ability to achieve these things (Feist Jess, 2017:168)." In this novel, Veronika is clearly depicted as a person who is an inferior person. ".... everything in her life is the same. As soon as her youth passed, everything would wither, old age began to leave signs that could not be repaired, infected with various diseases, and her friends are died. She will not gain anything by staying alive. Maybe it's just suffering that will increase (Coelho, 1998: 13)."

\section{b. The Contribution of the Main Character's Environments in Contribute to the Main Character's motivation for Life}

\section{1) Therapy}

As Albert Bandura states on the book entitled Theory of Personality, "The first step of successful therapy is to initiate some changes in behavior. The more important level of therapy is to generalize specific changes (Feist, 2017:170)." In this case Veronika depicted as a person who can hold their emotions. Nevertheless, she makes different action when she faced with something she had never experienced before. Previously she felt scared, sad, often withholding her anger. But Veronika shows that her actions it makes she not afraid again of it. This is proven when she lives in an asylum. She could not contain her anger. She chose to retaliate against those who have abused her. "..she never allowed himself to be provoked; from the first she learned that if a new situation arises she must be calm and keep his distance (Coelho,1998: 58)."

This quotation shows that she prefers to be quiet when she feels emotional or hateful in herself. Also, she chooses to hold back her anger rather than vent it. However, Veronika experienced something different when she lives in a mental hospital. There are some people who laughing at her. They are some people whose be the patients in those mental hospital. Veronika feels that she is being harassed because of their actions, so that she will get her revenge."..but the crazy people had humiliated her, made she afraid of anger, it make she want to kill them all, wanted to revile her with words she didn't dare to say (Coelho,1998: 58)." "She immediately approached the oldest man, who seemed to be their leader. Before anyone could prevent, Veronika slapped the man's face (Coelho,1998: 62).”

Meanwhile, during she lives in asylum, Veronika has make changes in herself. Starting from thoughts, feelings, and her attitudes. In this asylum, she plays the piano as she pleased, different when she lives with her mother. Her mother forbades her for playing piano, her mother is afraid because being a pianist did not guarantee for Veronika's life going forward. "She continued to play the piano, once, twice, ten times, twenty times, and the longer she felt that way, the hatred she felt grew faded until it finally vanished (Coelho,1998: 94)."

\section{2) Reciprocal Determinism}

As Albert Bandura states on the book entitled Theory of Personality, "Reciprocal is the mutual relationship between three factors, namely: behavior (B), cognitive and personal factors (P), and environmental influences $(\mathrm{E})$, each of which operates independently as a determining factor for other factors. Human behavior is the result of mutual interaction between external events and personal factors such as genetic abilities, competencies learned, reflective thoughts and initiatives (Feist, 2017:152)." When she lives in an asylum, Veronika has a friend 
named Mari. She is lawyer who has a panic attack. Mari gives lesson to her for become a strong woman which previously Veronika is a weak person also she feels unable to do anything. It makes Veronika feel that her life is useless. Therefore, she decides to suicide. Thanks to Mari, Veronika slowly began to understand that in her life she is free to do anything. Haven't you learned anything, even with death approaching? Don't constantly think that you are disturbing, that you are teasing the person next to you. If people don't like it, they can express it. And if they don't dare say it, then it's their own fault." At that time, when I approached you, I did things that I never dared to do. And you let yourself be a laughing stock of crazy people. Why don't you stick to your position"? "what's the loss? (Coelho,1998: 129)."

Moreover, Veronika also learned from her another friend named Zedka who suffered from platonic love. Zedka teaches about what life is like where Veronika has only a few days left. "I want to tell something. There are people who spend their whole lives looking for moments like you experienced last night, but never managed to achieve them. That is why, if you die now, you will die with a heart full of love. If I stay here longer, I will never come out again. My depression was cured, but in Villete I learned about other forms of insanity. I want to carry it and start seeing life with my own eyes (Coelho,1998: 211."

Furtermore, Veronika's another friend who gives her motivation to life named is Edward. "Then Veronika played music for stars, parks and mountains that were invisible in the dark, but she knew they were on the other side. When he plays music for the park, another crazy person appears: Edward, schizophrenic. He is not afraid; he just smiled, and was surprised to see the man returning his smile. The music he played apparently seemed to infiltrate the world of the man. (Coelho,1998: 95)."

\section{CONCLUSION}

In this study, the researcher found two main results. The first, this study indicated personality of Veronika as the main character in the novel Veronika Decides to Die based on the social cognitive theory concept that is dysfunction behavior. Based on concept of dysfunction behavior, it shows that Veronika is an introvert person, fainthearted, and suffering from depression. Second, this study discovered the main character's environments contribute to the character's motivation to life based on the social cognitive concepts, they are reciprocal determinism and therapy. Based on that theoretical concept, it shows that Veronika's environment really helps her to find her motivation to life. They are Mari, Zedka, and Edward.

\section{REFERENCES}

[1] Dickens, C. (1838). Oliver Twist,or, The Parish Boy's Progress. England: Richard Bentley.

[2] Abas, V. A., Saud, I. W., \& Husain, D. (2020). Slavery in Charles Dickens' novel Oliver Twist. NOTION: Journal of Linguistics, Literature, and Culture, Vol, 2(1), p. 51-57. https://doi.org/10.12928/notion.v2i1.1110

[3] Abrams, D., \& Hogg, M. A. (2010). Social identity and self-categorization. In J. F. Dovidio, M. Hewstone, P. Glick, \& V. M. Esses (Eds.), The $S A G E$ handbook of prejudice, stereotyping and discrimination, p. 179-193. London: Sage. http://dx.doi.org/10.4135/9781446200919.n11

[4] Thomas, J. (2019). Pyshcologist Define Motivation. USA: Laura Angers.

[5] La Macchia, S.T., \& Louis, W.R. (2016). Crowd behaviour and collective action. In S. McKeown, R. Haji, \& N. Ferguson (Eds.), Understanding peace and conflict through social identity theory: Theoretical, contemporary and worldwide perspectives. New York: Springer.

[6] Zolmedal. (2019). Paulo Coelho Biography. https://www.biography.com/writer/paulocoelho

[7] Yunus, M., Supiastutik, \& Suwargono, E. (2014). Is a study of life and death instinct in paulo coelho's veronica decide to die: A psychological approach. English Department Faculty of Letters, University of Jember.

http://repository.unej.ac.id/bitstream/handle/1 23456789/60676/Machmud\%20Yunus.pdf;sequ ence $=1$

[8] Coelho, P. (1988). Veronika Decides to Die. Brazil: ISBN. 10: 8172235437. 
https://www.academia.edu/24932169/Veronika Decides to Die Paulo Coelho

[9] McNabb. (2019). 5 Major Perspective in Psychology. http://mrmcnabb.weebly.com/5major-perspectives-in-psychology.html

[10]Gaurav, K. (2019). Psychological Depression, Feminism and Self-Realisation in Paulo Coelho's Veronika Decides to Die. JAC: Journal of Composition Theories, Vol. 12, p. 133-138.

http://www.jctjournal.com/gallery/18dec2019.pdf

[11]Aljannah, F. A. (2015). Reviving the passion of life through suicide of veronika's character in paulo coelho's veronika decides to die (Doctoral dissertation, UIN Sunan Ampel Surabaya). http://digilib.uinsby.ac.id/4252/8/Daftar\%20P ustaka.pdf

[12]Feist, J. (2017). Teori Kepribadian. Jakarta: Penerbit Salemba Humanika. 